\title{
Profile of Aberrant CpG Island Methylation Along the Multistep Pathway of Gastric Carcinogenesis
}

\author{
Gyeong Hoon Kang, Sun Lee, Jung-Sun Kim, and Hwoon-Yong Jung \\ Department of Pathology (GHK, SL), Seoul National University College of Medicine and Cancer Research Institute, \\ and Departments of Pathology (J-SK) and Internal Medicine (H-YJ), University of Ulsan College of Medicine, \\ Seoul, Korea
}

SUMMARY: To date, several reports on methylation of various genes in gastric cancer (GC) have been published. However, most of these studies focused on cancer tissues or a single gene only and gave no information about the methylation status of specific genes in the premalignant stages or about the concurrent methylation of other genes in specific lesions. We attempted to investigate methylation of multiple genes in a large sample collection of $\mathrm{GC}(n=80)$, gastric adenoma $(\mathrm{GA})(n=79)$, intestinal metaplasia (IM) $(n=57)$, and chronic gastritis (CG) $(n=74)$. We determined the methylation frequency of 12 genes, including APC, COX-2, DAP-kinase, E-cadherin, GSTP1, hMLH1, MGMT, p16, p14, RASSF1A, THBS1, and TIMP3 by methylation-specific PCR. Five different classes of methylation behaviors were found: (1) genes methylated in GC only (GSTP1 and RASSF1A); (2) genes showing low methylation frequency $(<12 \%)$ in $\mathrm{CG}$, IM, and GA, but significantly higher methylation frequency in GC (COX-2, hMLH1, and p16); (3) a gene with low and similar methylation frequency (8.8-21.3\%) in four-step lesions (MGMT); (4) genes with high and similar methylation frequency (53-85\%) in four-step lesions (APC and E-cadherin); and (5) genes showing an increasing tendency with or without fluctuation of the methylation frequency along the progression (DAP-kinase, p14, THBS1, and TIMP3). The average number of methylated genes was 2.7, 3.6, 3.4, and 5.2 per 12 tested genes in CG, IM, GA, and GC, respectively. Our results suggest that tumor suppressor genes show a gene type-specific methylation profile and that aberrant CpG island methylation tends to accumulate along the pathway of multistep carcinogenesis. (Lab Invest 2003, 83:635-641).

\begin{abstract}
I humans and most mammals, DNA methylation is 1 the only known endogenous modification of DNA, affecting only the cytosine residue when it precedes a guanosine residue. DNA methylation has an important role in the transcriptional repression of imprinted genes (Barlow, 1995) and genes on the inactivated $X$ chromosomes (Goto and Monk, 1998), maintaining the integrity of chromosomes (Erlich, 2000) or acting as a defense against highly repeated mobile elements (O'Neill et al, 1998). Aberrant methylation of CpG islands, which are normally protected from DNA methylation, is associated with DNA structural change and consequent gene inactivation. Aberrant methylation of promoter $\mathrm{CpG}$ islands is now recognized as an important mechanism for gene inactivation as an alternative to gene mutation or deletion in tumorigenesis (Baylin et al, 1998; Jones and Laird, 1999). Many tumors show simultaneous methylation of multiple genes involved in the tumorigenesis, including colon, hematologic, or uterine cervical cancers (Esteller et al, 2001; Toyota et al, 1999a, 2001; Virmani et al, 2001). Gastric cancer (GC) is one of the tumors with a high frequency of
\end{abstract}

\section{DOI: 10.1097/01.LAB.0000067481.08984.3F}

Received February 6, 2003.

This work was supported by Grant R02-2002-000-00040-0 from the Basic Research Program of the Korea Science and Engineering Foundation. Address reprint requests to: Dr. G. H. Kang, Department of Pathology, Seoul National University College of Medicine, 28 Yongon-dong, Chongno-gu, Seoul, 110-744, Korea. E-mail: ghkang@snu.ac.kr aberrant methylation (Kang et al, 2001; Toyota et al, 1999b).

An increasing number of genes that are inactivated by promoter $\mathrm{CpG}$ island hypermethylation have been reported in GC (Byun et al, 2001; lida et al, 2000; Kang et al, 2000; Leung et al, 1999; Oue et al, 2001; Shim et al, 2000; Song et al, 2001; Tamura et al, 2000; Tsuchiya et al, 2000). These genes have been identified by demonstrating the close link between $\mathrm{CpG}$ island methylation of the specific gene and loss of mRNA or protein in addition to reversal of the expression by treatment with demethylating agents. However, most of these studies have focused on aberrant methylation in a single gene. There have only been a few studies investigating the methylation status of multiple genes in GC (Leung et al, 2001; Suzuki et al, 1999; Toyota et al, 1999a). Furthermore, most of these studies were restricted to cancer tissues only, so the methylation status of a specific gene in the premalignant stages of GC was not analyzed. If aberrant methylation of the specific gene contributes to tumor initiation, the methylation change is expected to be found in the premalignant or early stages of the cancer.

We have previously studied the methylation of five genes: DAP-kinase, hMLH1, p16, THBS1, and TIMP3 in non-neoplastic and neoplastic gastric samples. We showed that $\mathrm{CpG}$ island methylation occurs early in multistep gastric carcinogenesis (Kang et al, 2001). In the present study, we extended the panel of tested genes from 5 to 12 and we studied the aberrant methylation of these loci for GCs and premalignant 
lesions. These genes are frequently methylated in cancers of the stomach or other organs and included the genes involved in cell cycle regulation $(p 14, p 16$, and COX-2), signal transduction (APC and RASSF1A), DNA repair or protection ( $h M L H 1, M G M T$, and GSTP1), apoptosis (DAP-kinase), and angiogenesis (THBS1) and those related to metastasis and invasion (E-cadherin and TIMP3). We analyzed the frequency of methylation of specific genes to determine the chronology and the extent of methylation during the multistep pathway of carcinogenesis from chronic gastritis (CG) to GC.

\section{Results}

We analyzed non-neoplastic and neoplastic gastric mucosa samples for the methylation status of $\mathrm{CpG}$ islands of the 12 genes using methylation-specific PCR (MSP). Tables 1 and 2 summarize the methylation frequency of each tested $\mathrm{CpG}$ island and the number of methylated genes in lesions of the each of the steps from CG to GC, respectively. Figure 1 displays representative examples of the MSP products analyzed by electrophoresis on an agarose gel. Methylation index was defined as the number of methylated genes divided by the number of tested genes. The average methylation index was $0.23,0.3$, 0.28 , and 0.43 in $\mathrm{CG}$, intestinal metaplasia (IM), gastric adenoma $(\mathrm{GA})$, and $\mathrm{GC}$, respectively. The methylation index was significantly higher for IM and GA than for CG ( $p=0.018$ and $p=0.034$, respectively, two-tailed $t$ test). A significant increase of methylation frequency from premalignant lesions (IM or GA) to $\mathrm{GC}$, but a similar methylation index between IM and GA, was noted (Fig. 2).

Bisulfite genomic sequencing of the representative MSP samples for each gene was performed, which validated the adequacy of the bisulfite modification and indicated that all of the cytosines at non-CpG sites were converted to thymines. All of the sequenced MSP prod- ucts showed extensive methylation of CpG sites between the MSP primer sequences as well as those CpG sites within the primer sequences. There were no differences between lesions at each step in either the number of methylated $\mathrm{CpG}$ sites or the methylation density of each CpG site. The vast majority of CpG sites, of all of the tested genes, exhibited methylation at a frequency greater than or equal to $75 \%$.

Forty pediatric gastric tissue samples were examined for the methylation status of 12 genes. These samples were obtained from pediatric patients who complained of epigastric discomfort and who underwent an endoscopic biopsy. All of the samples were diagnosed as CG without IM. The patients ranged from 2 to 17 years old, with an average age of 11 years. Table 3 summarizes the MSP results. COX2, DAP-kinase, GSTP1, hMLH1, and RASSF1A were not methylated at all in the pediatric gastric samples. One of the 40 samples showed $p 16$ methylation. MGMT and $p 14$ were methylated at a frequency of $2.5 \%$; APC, E-cadherin, THBS1, and TIMP3 were methylated at frequencies of $15 \%, 15 \%, 10 \%$, and $15 \%$, respectively. The methylation index of pediatric CG was 0.05 , and the maximum number of methylated genes was 4 . The earliest age when these genes were methylated was 2 years, although most of the cases with methylation of two or more genes were observed in patients older than 14 years. When the methylation frequency of each gene was compared between the pediatric and adult CG samples, significant differences were noted in APC, DAP-kinase, E-cadherin, and p14. Thus, methylation of these genes may be considered aging related.

\section{Discussion}

We analyzed promoter hypermethylation changes of 12 genes in DNA from the lesions of the four steps from CG to IM, GA, and GC. These genes possess

Table 1. Methylation Frequency of Each Gene in CG, IM, GA, and GC

\begin{tabular}{lccccr}
\hline & CG $(n=74)$ & IM $(n=57)$ & GA $(n=79)$ & GC $(n=80)$ & $p$ value \\
\hline APC & $48(64.9 \%)$ & $46(80.7 \%)$ & $57(72.2 \%)$ & $62(77.5 \%)$ & NS $^{a}$ \\
COX2 & $1(2.2 \%)$ & $5(8.8 \%)$ & $3(3.8 \%)$ & $37(46.3 \%)$ & $<0.001$ \\
DAP-K & $26(35.1 \%)$ & $28(49.1 \%)$ & $27(34.2 \%)$ & $45(56.3 \%)$ & 0.012 \\
E-cadherin & $63(85.1 \%)$ & $41(71.9 \%)$ & $46(58.2 \%)$ & $53(67.5 \%)$ & 0.003 \\
GSTP1 & 0 & 0 & 0 & $13(16.3 \%)$ & $<0.001$ \\
hMLH1 & 0 & $4(7 \%)$ & $7(8.9 \%)$ & $16(20 \%)$ & $<0.001$ \\
MGMT & $11(14.9 \%)$ & $5(8.8 \%)$ & $8(10.1 \%)$ & $17(21.3 \%)$ & NS \\
p14 & $22(29.7 \%)$ & $18(31.6 \%)$ & $60(75.9 \%)$ & $50(62.5 \%)$ & $<0.001$ \\
p16 & $2(2.7 \%)$ & $4(7 \%)$ & $9(11.4 \%)$ & $35(43.8 \%)$ & $<0.001$ \\
RASSF1A & 0 & 0 & 0 & $6(7.5 \%)$ & 0.001 \\
THBS1 & $13(17.6 \%)$ & $28(49.1 \%)$ & $27(34.2 \%)$ & $45(56.3 \%)$ & $<0.001$ \\
TIMP3 & $17(23 \%)$ & $25(43.9 \%)$ & $22(27.8 \%)$ & $52(65 \%)$ & $<0.001$ \\
Average number of & $2.7^{b}$ & $3.6^{c, d}$ & $3.4^{b, c}$ & $5.2^{d}$ & \\
methylated genes & & & & & \\
\hline
\end{tabular}

\footnotetext{
${ }^{a}$ Not significant $(p>0.05)$.

${ }^{b} \mathrm{CG}$ vs GA; $p=0.034$; Student's $t$ test.

${ }^{c}$ IM vs GA; $p=0.527$; Student's $t$ test.

${ }^{d} \mathrm{IM}$ vs GC; $p<0.001$; Student's $t$ test.
} 
Table 2. Frequency of Coincident Number of Gene Hypermethylation Events in CG, IM, GA, and GC

\begin{tabular}{|c|c|c|c|c|c|c|c|c|c|c|c|c|c|}
\hline $\begin{array}{c}\text { No. of } \\
\text { genes } \\
\text { methylated }\end{array}$ & 0 & 1 & 2 & 3 & 4 & 5 & 6 & 7 & 8 & 9 & 10 & 11 & 12 \\
\hline $\begin{array}{l}\mathrm{CG} \\
(n=74)\end{array}$ & $\begin{array}{c}3 \\
(4.1 \%)\end{array}$ & $\begin{array}{c}22 \\
(29.7 \%)\end{array}$ & $\begin{array}{c}17 \\
(23 \%)\end{array}$ & $\begin{array}{c}6 \\
(8.1 \%)\end{array}$ & $\begin{array}{c}11 \\
(14.9 \%)\end{array}$ & $\begin{array}{c}6 \\
(8.1 \%)\end{array}$ & $\begin{array}{c}8 \\
(10.8 \%)\end{array}$ & $\begin{array}{c}1 \\
(1.4 \%)\end{array}$ & & & & & \\
\hline IM & $\begin{array}{c}4 \\
\end{array}$ & 8 & 8 & $\begin{array}{c}6 \\
6\end{array}$ & $\begin{array}{c}11 \\
119 \%\end{array}$ & 8 & $\begin{array}{c}8 \\
1104\end{array}$ & $\begin{array}{c}2 \\
2\end{array}$ & $\begin{array}{c}2 \\
25\end{array}$ & & & & \\
\hline$(n=57)$ & (7\%) & $(14 \%)$ & $(14 \%)$ & $(10.5 \%)$ & $(19.3 \%)$ & $(14 \%)$ & $(14 \%)$ & $(3.5 \%)$ & $(3.5 \%)$ & & & & \\
\hline $\begin{array}{l}\text { GA } \\
(n=79)\end{array}$ & $\begin{array}{c}3 \\
(3.8 \%)\end{array}$ & $\begin{array}{c}10 \\
(12.7 \%)\end{array}$ & $\begin{array}{c}11 \\
(13.9 \%)\end{array}$ & $\begin{array}{c}17 \\
(21.5 \%)\end{array}$ & $\begin{array}{c}21 \\
(26.6 \%)\end{array}$ & $\begin{array}{c}8 \\
(10.1 \%)\end{array}$ & $\begin{array}{c}6 \\
(7.6 \%)\end{array}$ & $\begin{array}{c}1 \\
(1.3 \%)\end{array}$ & $\begin{array}{c}2 \\
(2.5 \%)\end{array}$ & & & & \\
\hline $\begin{array}{l}\mathrm{GC} \\
(n=80)\end{array}$ & $\begin{array}{c}3 \\
(3.8 \%)\end{array}$ & $\begin{array}{c}4 \\
(5 \%)\end{array}$ & $\begin{array}{c}5 \\
(6.3 \%)\end{array}$ & $\begin{array}{c}13 \\
(16.3 \%)\end{array}$ & $\begin{array}{c}6 \\
(7.5 \%)\end{array}$ & $\begin{array}{c}13 \\
(16.3 \%)\end{array}$ & $\begin{array}{c}8 \\
(10 \%)\end{array}$ & $\begin{array}{c}13 \\
(16.3 \%)\end{array}$ & $\begin{array}{c}6 \\
(7.5 \%)\end{array}$ & $\begin{array}{c}5 \\
(6.3 \%)\end{array}$ & $\begin{array}{c}3 \\
(3.8 \%)\end{array}$ & $\begin{array}{c}1 \\
(1.3 \%\end{array}$ & \\
\hline
\end{tabular}

\section{$A P C$ \\ COX-2 \\ $D A P K$ \\ E-cadherin \\ GSTP1 \\ hMLH1 \\ MGMT \\ $p 14$ \\ p16 \\ RASSF1A \\ THBS1 \\ TIMP3}

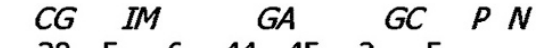
$\begin{array}{llllllll}28 & 5 & 6 & 44 & 45 & 3 & 5\end{array}$ $L \frac{28}{U M} \overline{U M} \overline{U M} \overline{U M} \overline{U M} \overline{U M} \overline{U M} M M$

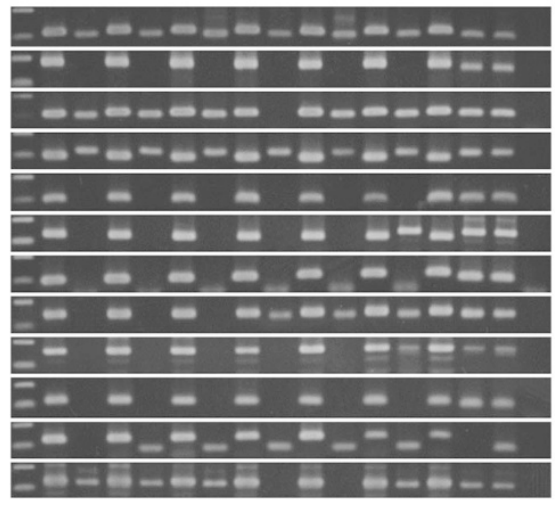

Figure 1.

Representative samples of methylation-specific PCR (MSP) analyses of DNA samples from chronic gastritis $(C G)$, intestinal metaplasia $(I M)$, gastric adenoma $(G A)$, and gastric carcinoma $(G C)$. The PCR products in the lanes marked $U$ show the presence of unmethylated templates of each gene, whereas the products in the lanes marked $M$ indicate the presence of methylated templates. $L=$ size marker (100-bp DNA ladder); $P=$ positive control; $N=$ negative control; $D A P K=$ DAP kinase. Positive control is normal lymphocyte DNA treated with Sss1 methyl transferase before bisulfite modification. Negative control is distilled water without template DNA.

$\mathrm{CpG}$ islands in their $5^{\prime}$ region; their inactivation by aberrant methylation of these CpG islands and their recovery from silencing by demethylation in GC and other cancers have been demonstrated. The genes tested included those involved in the important molecular pathways of carcinogenesis, such as cell cycle regulation, signal transduction, DNA repair or protection, apoptosis, and angiogenesis. However, most of the previous studies focused on the aberrant methylation of these genes in GC samples only, but did not involve a study of the methylation status of the genes in CG, IM, or GA. Without analysis of the methylation status of these genes in DNA from stages before GC, it cannot be clearly indicated whether the aberrant methylation of a specific gene is cancer-related or not.

If hypermethylation-associated inactivation of a specific gene contributes to tumor initiation, aberrant methylation might be found in the early lesions of the multistep pathway of gastric carcinogenesis. In the present study, 10 genes, excluding GSTP1 and
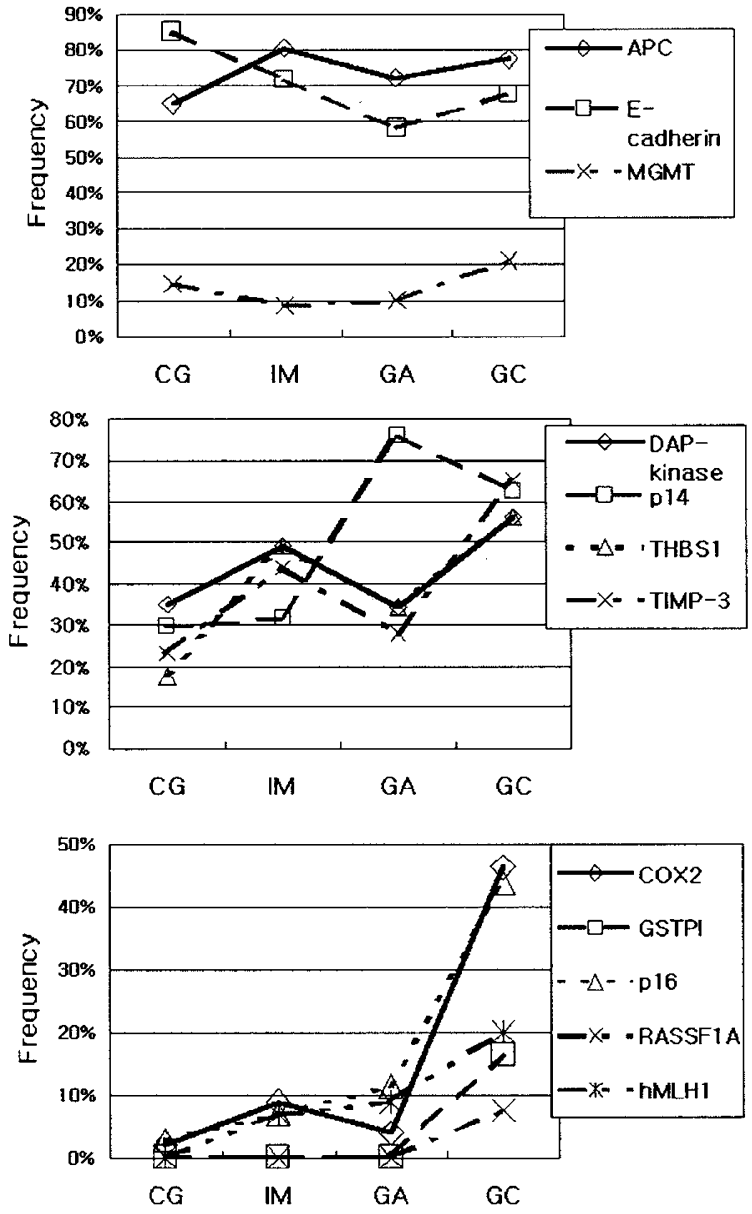

Figure 2.

Profiles of gene promoter hypermethylation along multistep gastric carcinogenesis. A gene with low and similar methylation frequency $(8.8 \%-21.3 \%)$ in the four-step lesions (MGMT) and genes with high and similar methylation frequency (58-85\%) in the four-step lesions (APC and E-cadherin) (upper). Genes showing an increasing tendency, with or without fluctuation, of methylation frequency along the progression (DAP-kinase, p14, THBS1, and TIMP3) (middle). Genes methylated in GC only (GSTP1 and RASSF1A) and genes showing low methylation frequencies $(<12 \%)$ in $\mathrm{CG}$, IM, and GA, but a significantly higher methylation frequency in GC (COX-2, hMLH1, and p16) (lower).

RASSF1A, were found to be methylated in CG, IM, or GA. However, the methylation frequency of $A P C$, E-cadherin, and MGMT was not different in lesions of each step, raising a question about the role of DNA 
Table 3. Comparison of Methylation Frequency of Each Gene Between Child and Adult CG

\begin{tabular}{lccc}
\hline & Child CG $(n=40)$ & Adult CG $(n=74)$ & $p$ value $^{a}$ \\
\hline APC & $6(15 \%)$ & $48(64.9 \%)$ & $<0.001$ \\
COX2 & 0 & $1(2.2 \%)$ & NS $^{b}$ \\
DAP-Kinase & 0 & $26(35.1 \%)$ & $<0.001$ \\
E-cadherin & $6(15 \%)$ & $63(85.1 \%)$ & $<0.001$ \\
GSTP1 & 0 & 0 & \\
hMLH1 & 0 & 0 & \\
MGMT & $1(2.5 \%)$ & $11(14.9 \%)$ & 0.054 \\
p14 & $1(2.5 \%)$ & $22(29.7 \%)$ & $<0.001$ \\
16 & $1(2.5 \%)$ & $2(2.7 \%)$ & NS \\
RASSF1A & 0 & 0 & NS \\
THBS1 & $4(10 \%)$ & $13(17.6 \%)$ & NS \\
TIMP3 & $6(15 \%)$ & $17(23 \%)$ & $<0.001$ \\
Average number of methylated genes & 0.6 & 2.7 & \\
\hline
\end{tabular}

${ }^{a}$ Analyzed by two-tailed Fisher's exact test.

${ }^{b}$ Not significant $(p>0.05)$.

methylation of these genes in the progression of the lesion along the multistep gastric carcinogenesis. DAP-kinase, p14, THBS1, and TIMP3 showed an increasing tendency of methylation frequency along the progression from CG to GC. COX-2, $h M L H 1$, and p16 were rarely methylated in CG, IM, and GA, and their methylation frequency showed at least a 2-fold increase from the premalignant lesions to GC. Thus, these, in addition to GSTP1 and RASSF1A, can be considered as cancer-related methylation genes.

In the present study, $12.2 \%$ of CG and $21 \%$ of IM samples showed concurrent methylation in at least seven of the tested genes. In these samples with a high frequency of methylation, the affected cells may have a growth-selective advantage imparted by the expressional loss of the methylated genes, which may predispose the cells to acquiring further genetic or epigenetic defects, which leads to neoplasia. If this is the case, a higher frequency of aberrant methylation would be expected in non-neoplastic gastric tissues for patients with GC. We investigated the methylation frequency of the 12 genes in 48 samples of nonneoplastic gastric mucosa from the patients with GC and found a methylation index of 0.48 , with $60.1 \%$ of the samples showing concurrent methylation of at least six of the tested genes (data not shown). These figures are significantly higher than those for CG or IM samples from patients without GC. These results were consistent with those of the study by Waki et al (2002), which showed increased methylation frequencies in non-neoplastic gastric mucosa from GC compared with non-neoplastic gastric mucosa without association of GC. A longitudinal prospective study would be required to confirm that patients with a high frequency of methylation in their gastric mucosa are at a higher risk of developing cancer.

We have studied a large collection of gastric samples, from CG to GC, for the methylation status of a panel of genes, and we determined the timing and frequency of aberrant methylation for specific genes along the multistep pathway of gastric carcinogenesis. We found that tumor suppressor genes showed a gene type-specific methylation profile along the multistep pathway of gastric carcinogenesis and that aberrant $\mathrm{CpG}$ island methylation occurred in the early stages and tended to accumulate along the multistep pathway of gastric carcinogenesis.

\section{Materials and Methods}

\section{DNA Preparation}

We studied 80 archival samples of surgically resected GC, 79 archival samples of GA, and 131 samples of endoscopically obtained non-neoplastic gastric mucosae (57 IM and $74 \mathrm{CG}$ ). After identification of carcinoma, adenoma, or intestinal metaplasia on hematoxylin and eosin-stained slides and marking the respective lesion on paraffin blocks, the marked areas were scraped from the paraffin blocks. The collected materials were dewaxed in xylene and rinsed in ethanol. The dried tissues were digested in a lytic solution containing proteinase $\mathrm{K}$, and the genomic DNA was purified with phenol/chloroform and by precipitation with ethanol.

\section{Methylation-Specific PCR}

Both normal and tumor DNAs were subjected to sodium bisulfite modification as described previously (Herman et al, 1996). In brief, $5 \mu \mathrm{g}$ of DNA was denatured with $2 \mathrm{M} \mathrm{NaOH}$, followed by treatment with $1 \mathrm{~mm}$ hydroquinone and $3.5 \mathrm{~m}$ sodium bisulfite and incubation for 16 hours at $55^{\circ} \mathrm{C}$. After purification using a JETSORB gel extraction kit (Genomed, Bad Oeynhausen, Germany), the DNA was treated with $3 \mathrm{~m}$ $\mathrm{NaOH}$ and precipitated with three volumes of $100 \%$ ethanol and a one-third volume of $7.5 \mathrm{M} \mathrm{NH}_{4} \mathrm{Ac}$ at $-20^{\circ} \mathrm{C}$. The precipitated DNA was washed with $70 \%$ ethanol and dissolved in distilled water. A panel of 12 genes were analyzed for their methylation status using MSP; the tested genes included APC, COX-2, DAPkinase, E-cadherin, GSTP1, hMLH1, MGMT, p14, p16, RASSF1A, TIMP3, and THBS1. The primer sequences of each gene, for methylated or unmethylated reac- 


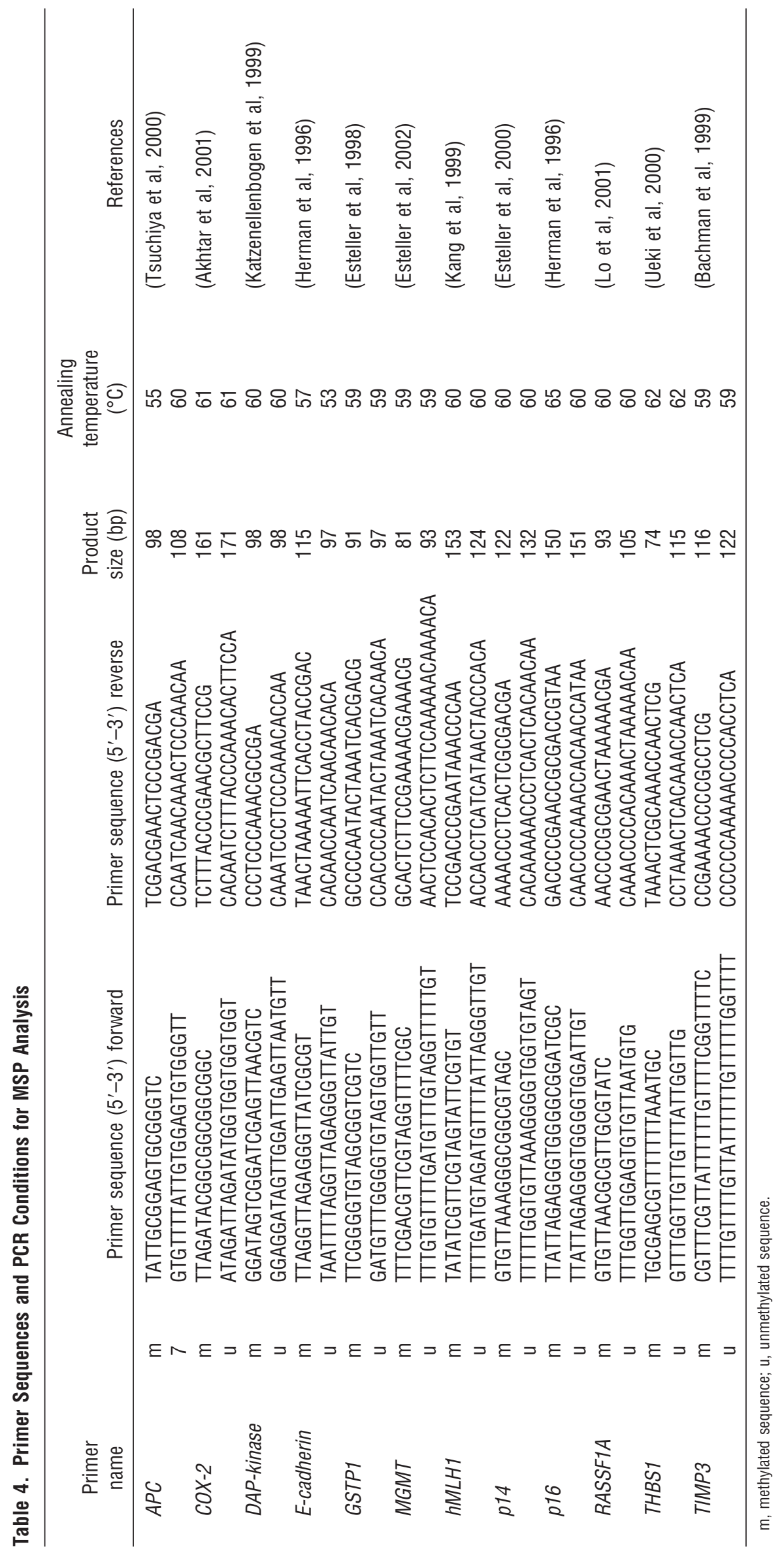


tions, are described in Table 4. The 25- $\mu$ l total reaction volume contained a PCR mixture of $1 \times$ PCR buffer (16.6 mM $\left(\mathrm{NH}_{4}\right)_{2} \mathrm{SO}_{4} ; 67 \mathrm{~mm}$ Tris, $\mathrm{pH} 8.8 ; 6.7 \mathrm{~mm}$ $\mathrm{MgCl}_{2} ; 10 \mathrm{~mm} \beta$-mercaptoethanol), dNTPs (each at 1 $\mathrm{mm}$ ), primers (10 pmol each), and bisulfite-modified DNA (30-50 ng). The reactions were hot-started at $97^{\circ} \mathrm{C}$ for 5 minutes before the addition of $0.75 \mathrm{U}$ of Taq polymerase (Takara Shuzo Company, Kyoto, Japan). The PCR conditions were as follows: 35 cycles of denaturation at $95^{\circ} \mathrm{C}$ for 40 seconds, annealing at the temperatures specified in Table 1 for 50 seconds, and finally a 50 -second extension at $72^{\circ} \mathrm{C}$. A final 10-minute extension at $72^{\circ} \mathrm{C}$ completed each PCR. The PCR products underwent electrophoresis on $2.5 \%$ agarose gels and were visualized after staining with ethidium bromide. Samples showing signals approximately equivalent to that of the size marker (7 $\mathrm{ng} / \mu \mathrm{l})$ were scored as methylated. Samples giving faint positive signals were repeated three times, and only those samples with consistent positive signals were regarded as methylated.

\section{Sequencing Analysis}

The PCR products were purified using a JETSORB gel extraction kit (Genomed) and cloned into the pCR2.1TOPO vector (Invitrogen, Carlsbad, California). Plasmid DNA was extracted from individual clones by an alkaline lysis plasmid minipreparation. The inserted PCR fragments of the four individual clones, obtained from each sample, were sequenced with both $M 13$ reverse and $M 13(-20)$ forward primers using an $A B I$ Prism 377 DNA Sequencer (Perkin-Elmer).

\section{References}

Akhtar M, Cheng Y, Magno RM, Ashktorab H, Smoot DT, Meltzer SJ, and Wilson KT (2001). Promoter methylation regulates Helicobacter pylori-stimulated cyclooxygenase-2 expression in gastric epithelial cells. Cancer Res 61:23992403.

Bachman KE, Herman JG, Corn PG, Merlo A, Costello JF, Cavenee WK, Baylin SB, and Graff JR (1999). Methylationassociated silencing of the tissue inhibitor of metalloproteinase-3 gene suggests a suppressor role in kidney, brain, and other human cancers. Cancer Res 59:798802.

Barlow DP (1995). Gametic imprinting in mammals. Science 270:1610-1613.

Baylin SB, Herman JG, Graff JR, Vertino PM, and Issa JP (1998). Alterations in DNA methylation: A fundamental aspect of neoplasia. Adv Cancer Res 72:141-196.

Byun DS, Lee MG, Chae KS, Ryu BG, and Chi SG (2001). Frequent epigenetic inactivation of RASSF1A by aberrant promoter hypermethylation in human gastric adenocarcinoma. Cancer Res 61:7034-7038.

Erlich M (2000). DNA methylation: Normal development, inherited diseases, and cancer. J Clin Ligand Assay 23:144146.

Esteller M, Corn PG, Baylin SB, and Herman JG (2001). A gene hypermethylation profile of human cancer. Cancer Res 61:3225-3229.
Esteller M, Corn PG, Urena JM, Gabrielson E, Baylin SB, and Herman JG (1998). Inactivation of glutathione S-transferase $\mathrm{P} 1$ gene by promoter hypermethylation in human neoplasia. Cancer Res 58:4515-4518.

Esteller M, Gaidano G, Goodman SN, Zagonel V, Capello D, Botto B, Rossi D, Gloghini A, Vitolo U, Carbone A, Baylin SB, and Herman JG (2002). Hypermethylation of the DNA repair gene $\mathrm{O}^{6}$-methylguanine DNA methyltransferase and survival of patients with diffuse large B cell lymphoma. J Natl Cancer Inst 94:26-32.

Esteller M, Tortola S, Toyota M, Capella G, Peinado MA, Baylin SB, and Herman JG (2000). Hypermethylationassociated inactivation of p14(ARF) is independent of p16(INK4a) methylation and p53 mutational status. Cancer Res 60:129-133.

Goto T and Monk M (1998). Regulation of X-chromosome inactivation in development in mice and humans. Microbiol Mol Biol Rev 62:362-378.

Herman JG, Graff JR, Myöhänen S, Nelkin BD, and Baylin SB (1996). Methylation-specific PCR: A novel PCR assay for methylation status of $\mathrm{CpG}$ islands. Proc Natl Acad Sci USA 93:9821-9826.

lida S, Akiyama Y, Nakajima T, Ichikawa W, Nihei Z, Sugihara $\mathrm{K}$, and Yuasa $\mathrm{Y}$ (2000). Alterations and hypermethylation of the p14(ARF) gene in gastric cancer. Int J Cancer 87:654658.

Jones PA and Laird PW (1999). Cancer epigenetic comes of age. Nat Genet 21:163-167.

Kang SH, Choi HH, Kim SG, Jong HS, Kim NK, Kim SJ, and Bang YJ (2000). Transcriptional inactivation of the tissue inhibitor of metalloproteinase-3 gene by DNA hypermethylation of the $5^{\prime}-\mathrm{CpG}$ island in human gastric cancer cell lines. Int J Cancer 86:632-635.

Kang GH, Shim YH, Jung HY, Kim WH, Ro JY, and Rhyu MG (2001). CpG island methylation in premalignant stages of gastric carcinoma. Cancer Res 61:2847-2851.

Kang GH, Shim YH, and Ro JY (1999). Correlation of methylation of the hMLH1 promoter with lack of expression of hMLH1 in sporadic gastric carcinomas with replication error. Lab Invest 79:903-909.

Katzenellenbogen RA, Baylin SB, and Herman JG (1999). Hypermethylation of the DAP-kinase CpG island is a common alteration in B-cell malignancies. Blood 93:4347-4353.

Leung WK, Yu J, Ng EK, To KF, Ma PK, Lee TL, Go MY, Chung SC, and Sung JJ (2001). Concurrent hypermethylation of multiple tumor-related genes in gastric carcinoma and adjacent normal tissues. Cancer 91:2294-2301.

Leung SY, Yuen ST, Chung LP, Chu KM, Chan AS, and Ho JC (1999). hMLH1 promoter methylation and lack of hMLH1 expression in sporadic gastric carcinomas with highfrequency microsatellite instability. Cancer Res 59:159-164.

Lo KW, Kwong J, Hui ABU, Chan SYY, To KF, Chan ASC, Chow LSN, Teo PML, Johnson PJ, and Huang DP (2001). High frequency of promoter hypermethylation of RASSF1A in nasopharyngeal carcinoma. Cancer Res 61:3877-3881.

O'Neill RJ, O'Neill MJ, and Graves JA (1998). Undermethylation associated with retroelement activation and chromosome remodelling in an interspecific mammalian hybrid. Nature 393:68-72. 
Oue N, Shigeishi H, Kuniyasu H, Yokozaki H, Kuraoka K, Ito $\mathrm{R}$, and Yasui W (2001). Promoter hypermethylation of MGMT is associated with protein loss in gastric carcinoma. Int $\mathrm{J}$ Cancer 93:805-809.

Shim YH, Kang GH, and Ro JY (2000). Correlation of p16 hypermethylation with $\mathrm{p} 16$ protein loss in sporadic gastric carcinomas. Lab Invest 80:689-695.

Song SH, Jong HS, Choi HH, Inoue H, Tanabe T, Kim NK, and Bang YJ (2001). Transcriptional silencing of cyclooxygenase-2 by hypermethylation of the $5^{\prime} \mathrm{CpG}$ island in human gastric carcinoma cells. Cancer Res 61:46284635.

Suzuki H, Itoh F, Toyota M, Kikuchi T, Kakiuchi H, Hinoda Y, and Imai K (1999). Distinct methylation pattern and microsatellite instability in sporadic gastric cancer. Int $\mathrm{J}$ Cancer 83:309-313.

Tamura G, Yin J, Wang S, Fleisher AS, Zou T, Abraham JM, Kong D, Smolinski KN, Wilson KT, James SP, Silverberg SG, Nishizuka S, Terashima M, Motoyama T, and Meltzer SJ (2000). E-cadherin gene promoter hypermethylation in primary human gastric carcinomas. J Natl Cancer Inst 92:569573.

Toyota M, Ahuja N, Ohe-Toyota M, Herman JG, Baylin SB, and Issa JP (1999a). CpG island methylator phenotype in colorectal cancer. Proc Natl Acad Sci USA 96:8681-8686.
Toyota M, Ahuja N, Suzuki H, Itoh F, Ohe-Toyota M, Imai K, Baylin SB, and Issa JP (1999b). Aberrant methylation in gastric cancer associated with the $\mathrm{CpG}$ island methylator phenotype. Cancer Res 59:5438-5442.

Toyota M, Kopecky KJ, Ohe-Toyota M, Jair KW, Willman CL, and Issa JP (2001). Methylation profiling in acute myeloid leukemia. Blood 2001:2823-2829.

Tsuchiya T, Tamura G, Sato K, Endoh Y, Sakata K, Jin Z, Motoyama T, Usuba O, Kimura W, Nishizuka S, Wilson KT, James SP, Yin J, Fleisher AS, Zou T, Silverberg SG, Kong D, and Meltzer SJ (2000). Distinct methylation patterns of two APC gene promoters in normal and cancerous gastric epithelia. Oncogene 19:3642-3646.

Ueki T, Toyota M, Sohn T, Yeo CJ, Issa JPJ, Hruban RH, and Goggins M (2000). Hypermethylation of multiple genes in pancreatic adenocarcinoma. Cancer Res 60:1835-1839.

Virmani AK, Muller C, Rathi A, Zoechbauer-Mueller S, Mathis M, and Gazdar AF (2001). Aberrant methylation during cervical carcinogenesis. Clin Cancer Res 7:584-589.

Waki T, Tamura G, Tsuchiya T, Sato K, Nishizuka S, and Motoyama T (2002). Promoter methylation status of E-cadherin, hMLH1, and p16 genes in nonneoplastic gastric epithelia. Am J Pathol 161:399-403. 